\title{
Durability Evaluation in Concrete Using Cracked Permeability and Chloride Permeability Tests
}

\author{
V. M. Sounthararajan and A. Sivakumar \\ Structural Engineering Division, School of Mechanical and Building Sciences, VIT University, Vellore, Tamil Nadu 632014, India \\ Correspondence should be addressed to A. Sivakumar; siva_iitm@rediffmail.com
}

Received 27 May 2013; Revised 1 July 2013; Accepted 19 July 2013

Academic Editor: Jörg M. K. Wiezorek

Copyright ( 2013 V. M. Sounthararajan and A. Sivakumar. This is an open access article distributed under the Creative Commons Attribution License, which permits unrestricted use, distribution, and reproduction in any medium, provided the original work is properly cited.

\begin{abstract}
The objective of this study is to identify the possibilities of utilizing the quarry dust in concrete to obtain an improved strength and durability properties of concrete. In the present study, the addition of quarry dust as alternative for natural sand has been investigated, and the durability properties of concrete were evaluated systematically by means of cracked water permeability and rapid chloride permeability tests. The permeability of concrete was assessed with initial stress applied to the concrete specimen and later checked for water permeability. Concrete mixes were casted using ordinary river sand and compared with $100 \%$ quarry dust substituted concrete. The addition of quarry dust significantly improved the concrete matrix properties in terms of strength and permeability resistance. The addition of fine quarry dust in concrete resulted in improved matrix densification compared to conventional concrete. Matrix densification has been studied qualitatively through petrographical examination using digital optical microscopy.
\end{abstract}

\section{Introduction}

In recent years, tremendous efforts have been made in the area of concrete technology to explore the utilization of industrial waste materials in the production of concrete. Quarry dust is a powder waste obtained during the crushing process of parent granite rock. It has recently gained good attention to be used as an effective filler material instead of fine aggregate. The successful utilization of these materials will result in the reduction of environmental load, waste management cost and concrete production cost, besides enhancing the properties of concrete in both fresh and hardened states. Efforts in this area have been focused on identifying and optimizing the benefits of different types of cement replacement materials as well as identifying alternative materials as aggregates in concrete [1]. The external causes may be physical, chemical, or mechanical and attack by natural or industrial aggressive liquids and gases. Most often the durability of concrete is assessed under nonideal condition without stressing. The durability of concrete is one of the most important properties because it is essential that concrete should be capable of withstanding the conditions for which it has been designed throughout the life span of a structure [2]. Lack of durability may be caused by external environmental reasons or internal causes within the concrete itself [3]. As for alternative materials used as aggregate fillers in concrete, numerous types of byproducts such as recycled concrete aggregate, quarry dust, fly ash, and slag, as well as several types of manufactured aggregates have been studied by many researchers. Several experimental studies showed that the influence of partial replacement of fine aggregate with crushed stone dust at varying percentages resulted in the improved properties of fresh and hardened concrete [4]. It can be observed that the permeability of concrete increased significantly when the stress level exceeds up to $40 \%$ of the ultimate strength of the concrete specimens [5]. Research studies also confirmed that the development of high-performance concrete using binary and ternary blended cementitious system at an optimum level of $8-12 \%$ of fine filler materials such as silica fume replaced with ordinary Portland cement showed improved strength and resulted in the reduction in oxygen permeability [6]. Also, investigations on the influence of supplementary cementing materials in concrete demonstrated an increased resistance of concrete 
against deterioration by aggressive chemicals and revealed that fineness of particle improves the permeability resistance of concrete $[7,8]$. In another study, it was found that the decrease in the coefficient of permeability occurred with time, which is expected due to continuous hydration in the specimen as well as potential pore-blocking [9]. The loss of the concrete durability may be caused by the severity of the environment to which it is exposed or by internal changes within the matured concrete itself [10]. Durability evaluation of concrete using gas permeability test can be an appropriate technique for measuring the permeation properties of concrete [11]. The addition of microfillers showed improved pore filling effects at lower water-to-binder ratio and also showed better performance in gas permeability. It can be observed that the permeability of concrete can be reduced by adding mineral admixture like silica fume up to $8 \%$, which makes the microstructure of concrete denser [12]. It is well realized that fine filler materials have been used for improving the matrix properties and thereby making the concrete highly impermeable [13]. Also, the use of alternative construction materials has been successfully utilized in different construction activities such as road construction and manufacturing of building materials such as lightweight aggregates, bricks, tiles, and autoclave blocks [14]. The durability of concrete can be defined as relatively impervious concrete microstructure even at stressed condition with crack closing forces under elastic crack opening mode [15]. Also, the previous experimental studies signifies that the durability of concrete depends on the long-term effects of concrete sustainability towards adverse environmental conditions as well as during operational loads when the structure is put in use. It can be summarized from the previous studies that the concrete structure put in use is subjected to initial loading due to selfweight which in turns produces cracking. This necessitates for testing permeability of concrete in stressed condition to evaluate the significant performance of concrete under cracked condition.

1.1. Research Significance. The present study focuses on evaluating the performance characteristics of quarry dustsubstituted concrete and to assess the durability properties of concrete. Durability measurements were quantified using cracked permeability and rapid chloride permeability test methods. Cracked permeability of concrete is an important measure determined in this study which provides an actual estimation on the permeability properties of concrete under stressed conditions. This serves as a real quantification of concrete durability subjected to initial crack opening when subjected to service loading. In this regard, the concrete specimens were tested by giving an initial stress up to $40 \%$ of its ultimate load and measuring the weight gaining of concrete kept in concrete permeability equipment.

\section{Experimental Investigations}

The details of concrete making materials used in the present study are as follows.

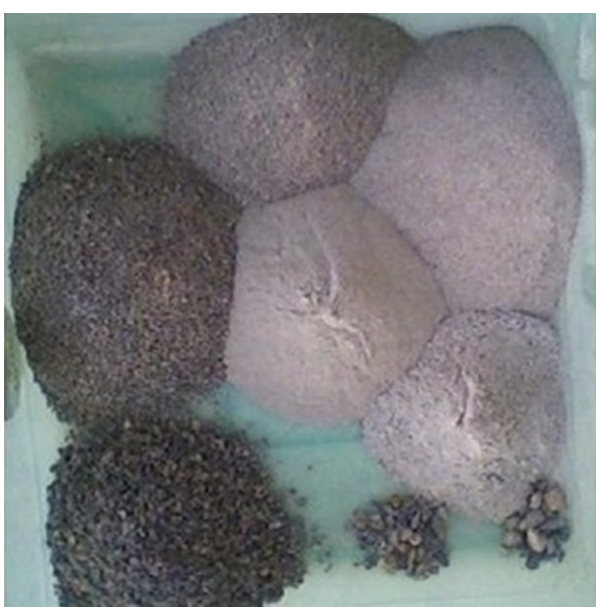

Figure 1: Different size fractions of quarry dust.

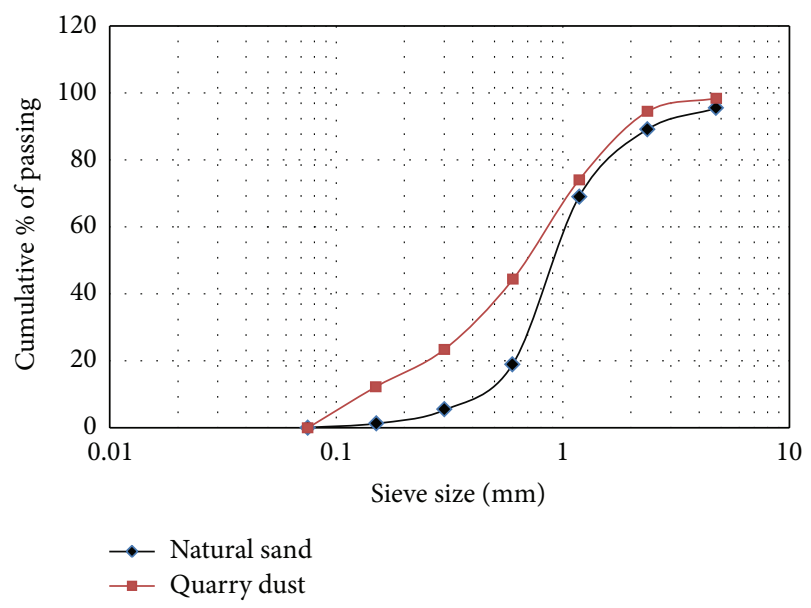

FIGURE 2: Sieve analysis of river sand and quarry dust.

\subsection{Constituent Materials}

2.1.1. Cement. Ordinary Portland cement of grade 53 which had a specific gravity of 3.14 and Blaine fineness of $315 \mathrm{~m}^{2} / \mathrm{kg}$ was used.

2.1.2. Aggregates Used. A river sand conforming to zone II as per IS 383-1970 [16] was used for preparing conventional river sand concrete, and quarry dust was used as its $100 \%$ replacement. The specific gravity value of sand was 2.3 and the loose bulk density values of sand were $1455 \mathrm{~kg} / \mathrm{m}^{3}$ and $1726 \mathrm{~kg} / \mathrm{m}^{3}$, respectively. The snapshot of quarry dust with different size ranges is shown in Figure 1, and the gradation curve for river sand and quarry dust is shown in Figure 2. The specific gravity of quarry dust was found to be 1.95 and the bulking of quarry dust value was around $34.13 \%$. Crushed granite was used as coarse aggregate which was passing through $20 \mathrm{~mm}$ and retained on $12 \mathrm{~mm}$ Sieve with a specific gravity value of 2.65 . The loose and compacted bulk density values of coarse aggregate were $1483 \mathrm{~kg} / \mathrm{m}^{3}$ and $1680 \mathrm{~kg} / \mathrm{m}^{3}$, respectively. 
TABLE 1: Various concrete mixture proportions used in the study.

\begin{tabular}{|c|c|c|c|c|c|c|c|c|}
\hline Mix Id & $\mathrm{F} / \mathrm{C}$ ratio & Cement & Fine aggregate & Quarry dust & $\begin{array}{l}\text { Coarse aggregate } \\
\left(\mathrm{m}^{3}\right)\end{array}$ & Water & Superplasticizer & $\mathrm{w} / \mathrm{c}$ \\
\hline M1 & 0.6 & 300 & 788 & 0 & 1313 & 420 & 2.4 & 0.35 \\
\hline M2 & 0.7 & 300 & 865 & 0 & 1313 & 395 & 2.4 & 0.35 \\
\hline M3 & 0.8 & 300 & 933 & 0 & 1313 & 373 & 2.4 & 0.35 \\
\hline M4 & 0.6 & 300 & 0 & 788 & 1333 & 420 & 2.4 & 0.35 \\
\hline M5 & 0.7 & 300 & 0 & 865 & 1333 & 395 & 2.4 & 0.35 \\
\hline M6 & 0.8 & 300 & 0 & 933 & 1333 & 373 & 2.4 & 0.35 \\
\hline M7 & 0.6 & 350 & 769 & 0 & 1281 & 410 & 2.8 & 0.35 \\
\hline M8 & 0.7 & 350 & 844 & 0 & 1206 & 386 & 2.8 & 0.35 \\
\hline M9 & 0.8 & 350 & 911 & 0 & 1139 & 364 & 2.8 & 0.35 \\
\hline M10 & 0.6 & 350 & 0 & 769 & 1281 & 410 & 2.8 & 0.35 \\
\hline M11 & 0.7 & 350 & 0 & 844 & 1206 & 386 & 2.8 & 0.35 \\
\hline M12 & 0.8 & 350 & 0 & 911 & 1139 & 364 & 2.8 & 0.35 \\
\hline M13 & 0.6 & 400 & 750 & 0 & 1250 & 400 & 2.8 & 0.35 \\
\hline M14 & 0.7 & 400 & 824 & 0 & 1176 & 376 & 2.8 & 0.35 \\
\hline M15 & 0.8 & 400 & 889 & 0 & 1111 & 356 & 3.2 & 0.35 \\
\hline M16 & 0.6 & 400 & 0 & 750 & 1250 & 400 & 3.2 & 0.35 \\
\hline M17 & 0.7 & 400 & 0 & 824 & 1176 & 376 & 3.2 & 0.35 \\
\hline M18 & 0.8 & 400 & 0 & 889 & 1111 & 356 & 3.2 & 0.35 \\
\hline
\end{tabular}

2.1.3. Chemical Admixture Used. In order to improve the workability properties of concrete and to avoid the harshness of the concrete at low water content, the addition of chemical admixtures was found to be essential. In the present study, a polycarboxylate-ether-based superplasticizer was used at an optimum dosage of $2.5 \%$ (by weight of cement). The mix water used for preparing concrete specimens was free of chlorides and sulphates.

\subsubsection{Concrete Mixture Proportions and Curing. A target con-} crete strength of $35 \mathrm{~N} / \mathrm{mm}^{2}$ was designed as per IS 10262-2009 [17], and the detailed mixture proportions of concrete used in the test program are given in Table 1. A total of eighteen different concrete mixes were designated from M1 to M18 and were proportioned based on the water-to-cement ratio of 0.3 , cement content varied from $300 \mathrm{~kg} / \mathrm{m}^{3}$ to $400 \mathrm{~kg} / \mathrm{m}^{3}$, and fine aggregate to coarse aggregate $(\mathrm{F} / \mathrm{C})$ ratio was $0.6,0.7$, and 0.8 . The conventional concrete containing river sand and quarry dust-substituted concrete were prepared for studying the strength and durability properties. The desired workability of all concrete mixes was maintained using superplasticizer at a maximum dosage restricted to $2.5 \%$ by weight of the binder. A horizontal pan mixer of 40-litre capacity was used for mixing the constituent material. Fresh concrete was casted in $100 \mathrm{~mm}$ cubes moulds, and after a day the specimens were remoulded and were cured in the water tank at $35^{\circ} \pm 3^{\circ} \mathrm{C}$.

\subsubsection{Rapid Chloride and Cracked Permeability Test Methods.} The rapid chloride penetration test was conducted as per ASTM C 1202-1997 [18] with a concrete disc specimen of size $100 \mathrm{~mm}$ diameter and $50 \mathrm{~mm}$ thick. This test method was useful for the determination of the electrical conductance of concrete to provide a rapid indication of its resistance to the penetration of chloride ions. The test method consisted of monitoring the amount of electrical current passed through cylinders for a 6-hour period (log time), and recording was maintained at every 30-minute interval. The cracked permeability of concrete was determined in accordance with IS 3085-1965 [19]. Permeability was determined in plain and quarry dust concrete by means of initial loading applied on the concrete specimens and measuring the weight of concrete gained due to ingress of water upon microcracking. A constant pressure of $5 \mathrm{~kg} / \mathrm{cm}^{2}$ was given for all the concrete mixtures, and the reading in the graduated glass limb of the concrete permeability test setup was noted for the amount of water entering the cracked specimen.

\section{Experimental Test Results and Discussions}

3.1. Compressive Properties. The experimental test results on the compressive properties of all quarry dust-substituted concrete mixes investigated showed a reasonable strength attainment above $35 \mathrm{~N} / \mathrm{mm}^{2}$ (28 days) which was higher than controlled concrete. However, there was a significant increase in the compressive strength for all quarry dust replaced concrete mixes compared to conventional river sand concrete mixes. A high strength of $50 \mathrm{~N} / \mathrm{mm}^{2}$ was reported for M17 concrete mix containing F/C ratio 0.7 and $400 \mathrm{~kg} / \mathrm{m}^{3}$, which was $15 \%$ higher than conventional concrete (M15). This trend was observed to be similar for all quarry dust concrete mixes at different cement content. It can be inferred from the test results that the addition of quarry dust particles improves the matrix properties of concrete systems due to closer granular packing along with binder particles. This eventually contributed for a well-developed matrix system with low porosity and high densification of the mortar phase leading to improved compressive properties. 


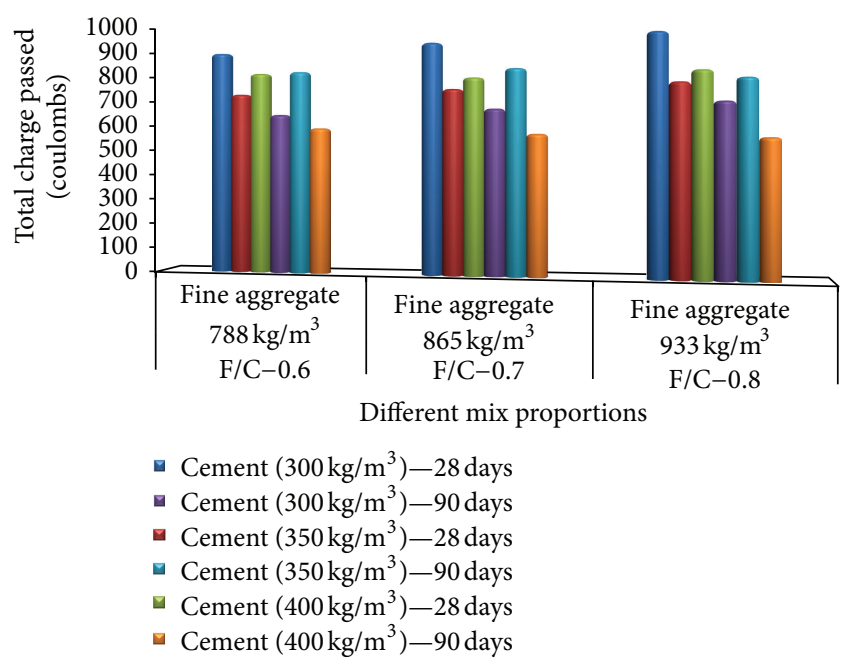

FIGURE 3: RCPT for various mixture proportions of concrete without quarry dust.

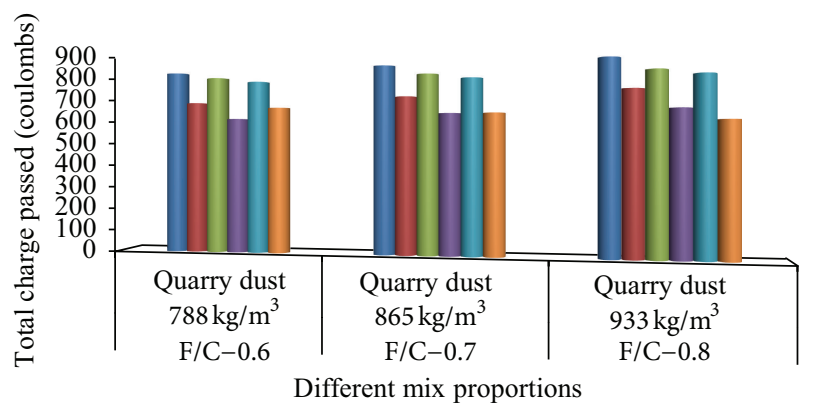

- Cement $\left(300 \mathrm{~kg} / \mathrm{m}^{3}\right)-28$ days

- Cement $\left(350 \mathrm{~kg} / \mathrm{m}^{3}\right)-28$ days

- Cement $\left(400 \mathrm{~kg} / \mathrm{m}^{3}\right)-28$ days

- Cement $\left(300 \mathrm{~kg} / \mathrm{m}^{3}\right)-90$ days

- Cement $\left(350 \mathrm{~kg} / \mathrm{m}^{3}\right)-90$ days

- Cement $\left(400 \mathrm{~kg} / \mathrm{m}^{3}\right)-90$ days

FIGURE 4: RCPT for various mixture proportions of concrete with quarry dust.

3.2. Rapid Chloride Penetration Test (RCPT). The rapid chloride penetration test results for various concrete mixtures with and without quarry dust addition are provided in Table 2 and represented in Figures 3 and 4 . It can be observed from the test results that the average charge passing through the conventional concrete containing river sand showed a reduction in chloride permeability compared to same cement content with higher F/C ratio. However, the addition of quarry dust in concrete drew lesser current than conventional concrete because of high matrix densification provided by the quarry dust. It can be also noted that the reduction in chloride permeability was appreciable for quarry dust concrete mixtures at higher cement content. The experimental trends for various concrete mixtures containing quarry dust showed that the average charge passing through the concrete specimens for 180 minutes duration were observed to fall
TABLE 2: Compressive strength and rapid chloride permeability test values for different concrete mixes.

\begin{tabular}{lcccc}
\hline Mix Id & $\begin{array}{c}\text { Compressive strength } \\
\left(\mathrm{N} / \mathrm{mm}^{2}\right)\end{array}$ & \multicolumn{2}{c}{ RCPT charge passed } \\
& 28 days & 90 days & 28 days & 90 days \\
\hline M1 & 33.9 & 42.3 & 900 & 730 \\
M2 & 36.2 & 45.7 & 930 & 745 \\
M3 & 34.2 & 41.9 & 960 & 765 \\
M4 & 35.8 & 44.1 & 830 & 690 \\
M5 & 36.6 & 45.9 & 850 & 710 \\
M6 & 34.9 & 42.5 & 870 & 735 \\
M7 & 35.1 & 45.3 & 815 & 645 \\
M8 & 38.7 & 47.4 & 790 & 665 \\
M9 & 34.0 & 43.9 & 810 & 690 \\
M10 & 37.5 & 46.1 & 805 & 615 \\
M11 & 38.4 & 48.2 & 810 & 635 \\
M12 & 34.9 & 44.0 & 815 & 650 \\
M13 & 37.3 & 46.9 & 820 & 590 \\
M14 & 39.1 & 47.4 & 825 & 565 \\
M15 & 35.2 & 44.5 & 780 & 550 \\
M16 & 40.5 & 47.4 & 785 & 665 \\
M17 & 42.8 & 50.4 & 790 & 635 \\
M18 & 37.9 & 46.0 & 795 & 600 \\
\hline
\end{tabular}

within the low permeability range as specified in ASTM C 1202. Therefore, it indicates that $100 \%$ quarry dust-substituted concrete was compromising the improved microstructural development without affecting the durability properties of concrete. The test results necessarily indicate that the durability properties of concrete primarily depend on the pore structure formation at various curing periods. Hence, refined microstructural alterations in concrete can be observed with suitable additions of fine fillers and further optimizing the voids by effective packing. It is understood from the quarry dust-substituted concrete that different percentages of finer fractions of granular materials provide adequate dense microstructure. This results in an improved performance of quarry dust concrete compared to conventional cement concrete. Concrete materials subjected to long-term weather deteriorate faster in aggressive conditions due to initial porosity. This test method serves to be an ideal method for identifying the permeability properties of concrete under aggressive environmental conditions, since chloride laden water causes corrosion initiation faster in steel-embedded concrete.

3.3. Cracked Permeability of Concrete. The concrete permeability in this study was tested in cracked concrete specimens with an initial load (40\% of ultimate load) applied on it and later checked for the water permeability under constant pressure. From the experimental test results shown in Figures 5,6 , and 7 , it can be noted that the coefficient of permeability values of conventional river sand concrete mixes was found to be decreasing at higher $\mathrm{F} / \mathrm{C}$ ratio of 0.8 . However, in the case 


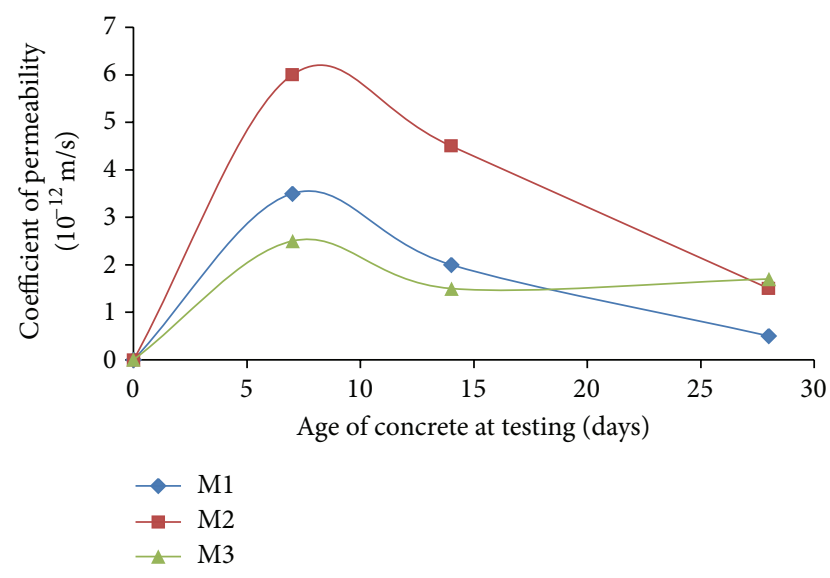

FIGURE 5: Effect of river sand on the cracked permeability of concrete at $300 \mathrm{~kg} / \mathrm{m}^{3}$ of cement.

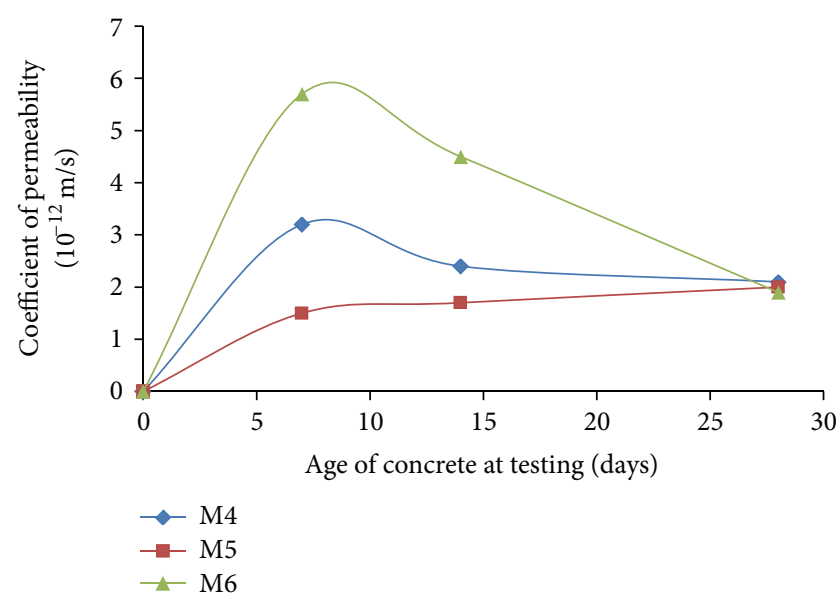

FIGURE 6: Effect of quarry dust on the cracked permeability of concrete at $300 \mathrm{~kg} / \mathrm{m}^{3}$ of cement.

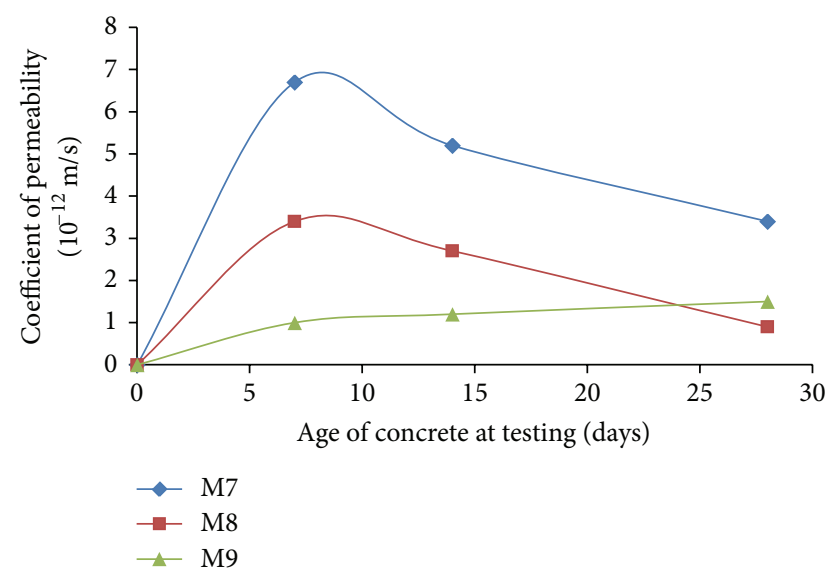

FIGURE 7: Effect of river sand on the cracked permeability of concrete at $350 \mathrm{~kg} / \mathrm{m}^{3}$ of cement.

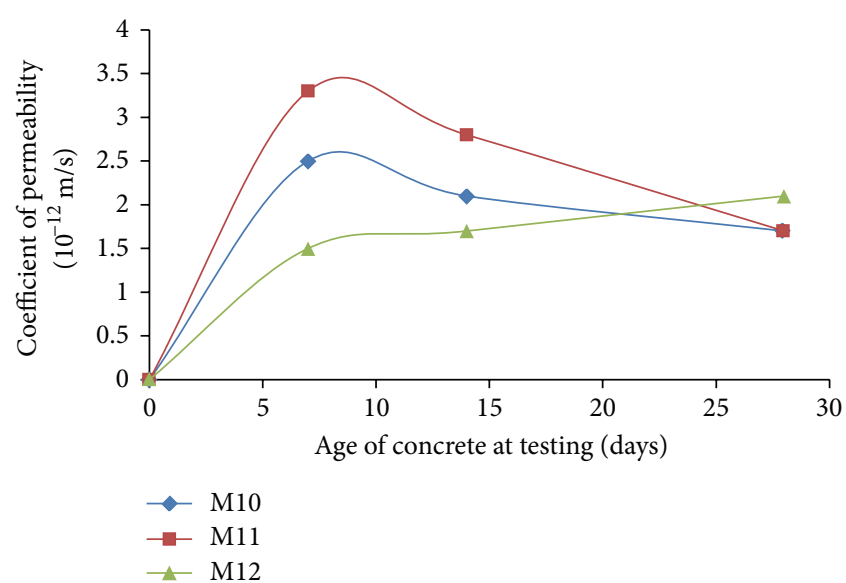

FIGURE 8: Effect of quarry dust on the cracked permeability of concrete for $350 \mathrm{~kg} / \mathrm{m}^{3}$ of cement.

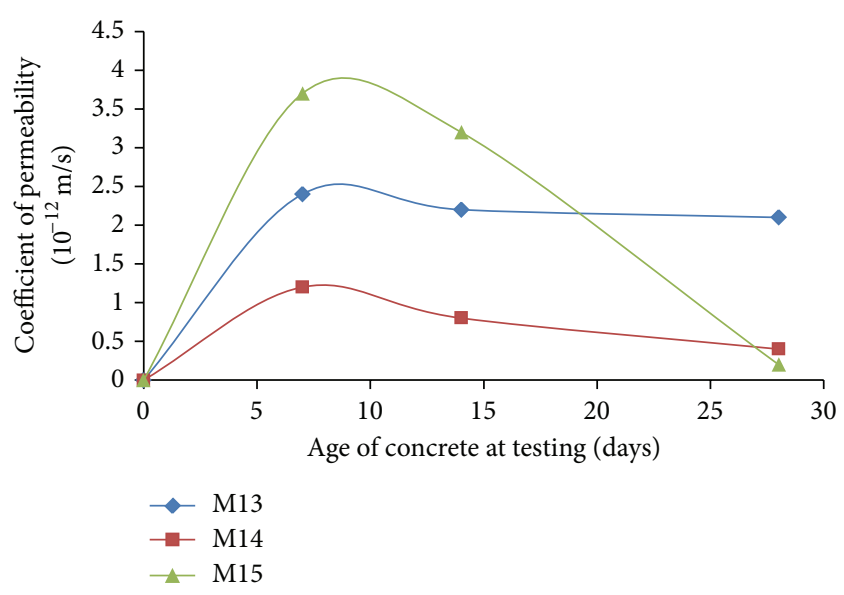

FIGURE 9: Effect of river sand on the cracked permeability of concrete for $400 \mathrm{~kg} / \mathrm{m}^{3}$ of cement.

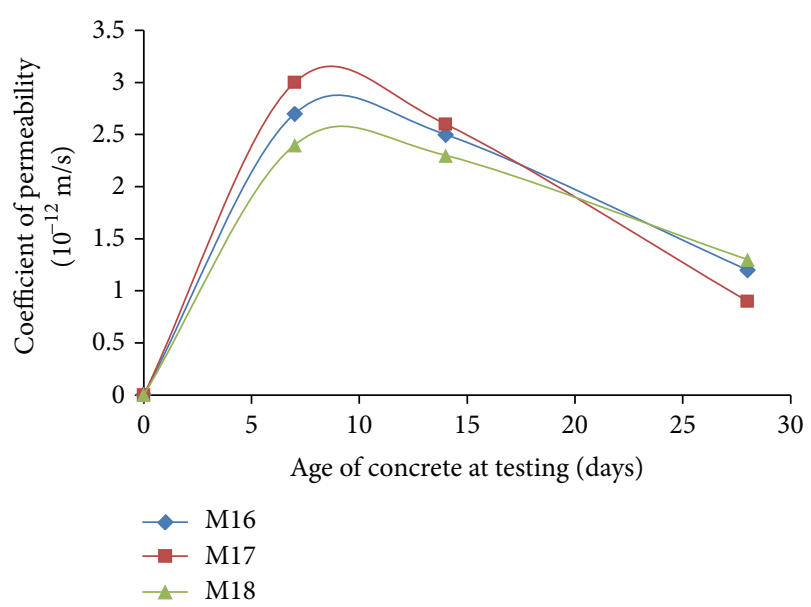

FIGURE 10: Effect of quarry dust on the cracked permeability of concrete with $400 \mathrm{~kg} / \mathrm{m}^{3}$ of cement. 


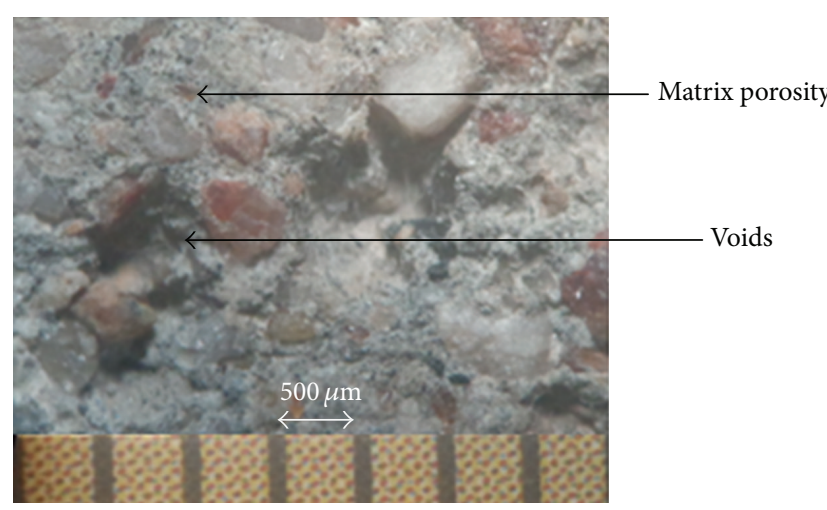

(a)

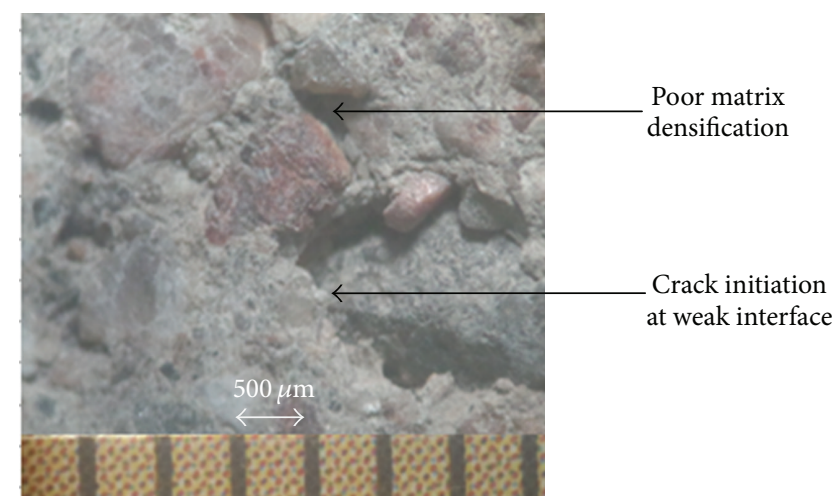

(b)

Figure 11: (a) Microscopic view of conventional concrete without initial stress (50x magnification). (b) Microscopic view of conventional concrete at $40 \%$ load (50x magnification).

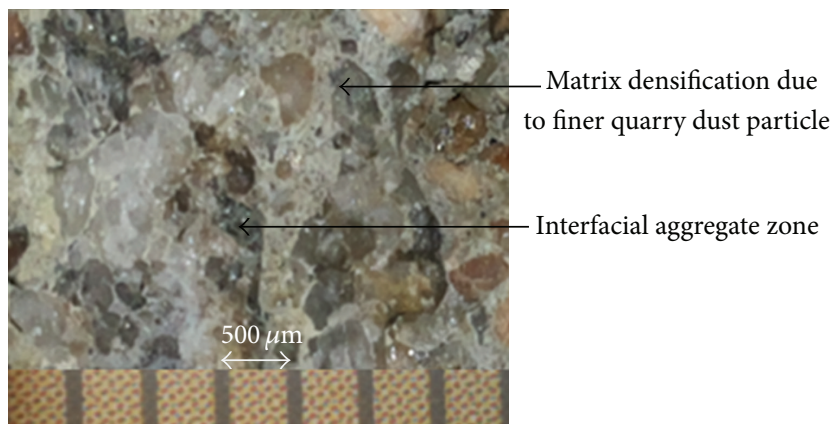

(a)

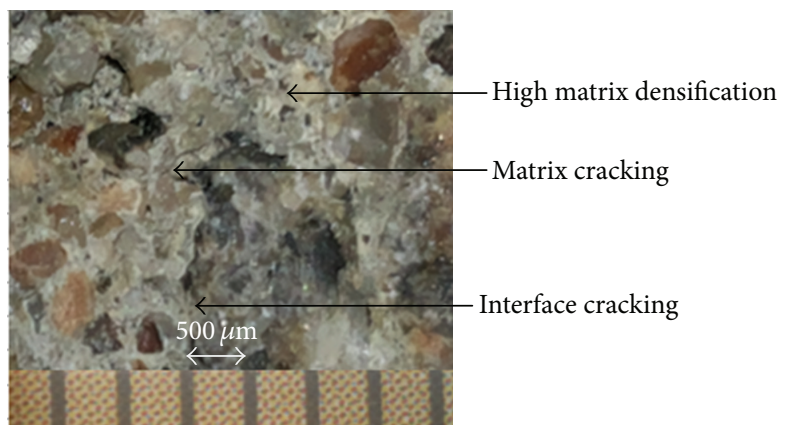

(b)

FIGURE 12: (a) Microscopic view of quarry dust concrete without stress (50x magnification). (b) Microscopic view of quarry dust concrete at $40 \%$ load (50x magnification).

of quarry dust-substituted concrete the permeability coefficient was found to be reduced appreciably for all $\mathrm{F} / \mathrm{C}$ ratios compared to conventional river sand-substituted concrete which can be observed from Figures 8, 9, and 10. It can be observed from experimental trends that with the increase in cement content and $\mathrm{F} / \mathrm{C}$ ratio the permeability coefficient was reduced significantly. This essentially shows that quarry dustsubstituted concrete had improved matrix strengthening due to efficient granular packing and provided crack resistance for the initial stress levels. Also, it can be noted that compared to conventional river sand concrete mixes, the quarry dust (M18) concrete showed a reduction in permeability up to $44 \%$ at higher cement content of $400 \mathrm{~kg} / \mathrm{m}^{3}$ and $\mathrm{F} / \mathrm{C}$ of 0.8 (as seen in Figure 10). It can be understood from the results that the incorporation of finer quarry dust particles in place of river sand had shown a significant crack-resisting properties at initial loading.

From the test results, it can be noted that for high cementitious content with increased cracking stress, the distribution of microcracking is restricted in quarry dust concrete due to the delay in crack formation. Compared to river sand, quarry dust concrete showed a considerable reduction in cracked permeability for all cement contents at higher $\mathrm{F} / \mathrm{C}$ ratio. The test results exhibited an appreciable reduction in the cracked permeability of quarry dust-incorporated concrete mixtures compared to all other conventional concrete mixes. Concrete petrography studies were conducted using digital microscope of $50 \mathrm{x}$ magnification to identify the interfacial properties of conventional river sand concrete mixes compared to those of quarry dust-substituted concrete mixes. Concrete slices of size $25 \times 25 \mathrm{~mm}$ were cut from different regions of casted concrete sections of actual size of $100 \mathrm{~mm} \times 100 \mathrm{~mm}$. The micrograph shown in Figure 11(a) was captured for controlled concrete mix (M1) without initial stress which revealed the weak interfacial zone between aggregate and large void formations in the matrix. In the case of initial stress applied to conventional concrete, the cracking near the voids occurred rather than in the interfacial region which can be seen in Figure 11(b). However, in the case of quarry dust-substituted concrete mix (M11), the distribution of finer sizes of particles was able to increase the matrix densification as evidently seen in Figure 12(a). Also, it can be concluded from Figure 12(b) that upon the application of initial loading the aggregate cracking at the interface occurred rather than matrix cracking due to higher elastic modulus of matrix. The microstructural results also confirm that the improvement 
of matrix properties are better realized in quarry dustsubstituted concrete compared to conventional river sand concrete mixes.

Microcracks at transition zone are known for causing the permeability whereas matrix densification can delay the crack propagation. It may be justified that microcracks in the initial stage are so small that they may not increase the permeability. But the propagation of microcracks with time due to externally applied load will increase the permeability of the concrete and provide a reliable estimate on the actual permeation resistance of cementitious systems.

\section{Conclusions}

Based on the experimental investigation, the following conclusions are drawn within the limitations of the test results.

(i) Fresh concrete properties of concrete substituted with quarry dust showed a slight reduction in consistency and was reinstated with the addition of superplasticizer to obtain the desired workability of 75 to $100 \mathrm{~mm}$.

(ii) Compressive properties of quarry dust-substituted concrete had shown significant strength enhancement at higher $\mathrm{F} / \mathrm{C}$ ratio (0.8) and cement content $\left(400 \mathrm{~kg} / \mathrm{m}^{3}\right)$, and a maximum strength of $50 \mathrm{~N} / \mathrm{mm}^{2}$ was obtained. This reveals the fact that high matrix densification as a result of fine particles present in quarry dust provided good granular packing.

(iii) The cracked permeability experimental test results showed that the addition of the quarry dust improved the permeation resistance of concrete. This can be seen from the concrete mixes containing $100 \%$ quarry dust instead of river sand for the mixes M6, M12, and M18 which showed a substantial reduction in the coefficient of permeability values up to $40 \%$, and the reduction was significant for higher cement content $\left(400 \mathrm{~kg} / \mathrm{m}^{3}\right)$ as well as for higher F/C ratio of 0.8 .

(iv) It can also be noted from the chloride permeability test results that the permeation resistance was higher for quarry dust concrete compared to river sand concrete specimens.

(v) However, it is concluded from quarry dust concrete that the permeability of concrete is controlled due to inhibition of the crack opening and requires higher stress for further opening and propagation. This is evident from the cracked water permeability test results as well as chloride permeability test results. Compared with natural sand, 100\% quarry dust replacement in concrete showed the considerable reduction in cracked permeability and chloride permeability at higher cement content and higher F/C ratio.

(vi) It is also understood from the particle size analysis that the fineness of quarry dust led to the improved pore structure properties leading to matrix densification properties. This is evidently seen from the digital microscopy studies that the porosity of conventional concrete mixes were more and resulted in matrix cracking whereas a refined matrix densification is achieved with the quarry dust substitution.

(vii) The study also signifies that the durability of concrete is dictated due to initiation of microcracks upon initial stress applied and becomes adverse due to capillary movement of water.

(viii) It can be concluded from the test results that the addition of alternative fine aggregate material such as quarry dust in concrete can be a potential application for mass concreting works in order to reduce the river sand depletion.

\section{References}

[1] M. Vijayalakshmi, A. S. S. Sekar, and G. Ganesh prabhu, "Strength and durability properties of concrete made with granite industry waste," Construction and Building Materials, vol. 46, pp. 1-7, 2013.

[2] J. Sobhani, M. Najimi, and A. R. Pourkhorshidi, "Effects of retempering methods on the compressive strength and water permeability of concrete," Scientia Iranica, vol. 19, no. 2, pp. 211217, 2012.

[3] H. A. F. Dehwah, "Mechanical properties of self-compacting concrete incorporating quarry dust powder, silica fume or fly ash," Construction and Building Materials, vol. 26, no. 1, pp. 547551, 2012.

[4] S. A. Abukersh and C. A. Fairfield, "Recycled aggregate concrete produced with red granite dust as a partial cement replacement," Construction and Building Materials, vol. 25, no. 10, pp. 40884094, 2011.

[5] S.-T. Yi, T.-Y. Hyun, and J.-K. Kim, "The effects of hydraulic pressure and crack width on water permeability of penetration crack-induced concrete," Construction and Building Materials, vol. 25, no. 5, pp. 2576-2583, 2011.

[6] F. K. Thomas and P. Partheeban, "Study on the effect of granite powder on concrete properties," Proceedings of Institution of Civil Engineers, vol. 163, no. 2, pp. 63-70, 2010.

[7] H.-W. Song, S.-W. Pack, S.-H. Nam, J.-C. Jang, and V. Saraswathy, "Estimation of the permeability of silica fume cement concrete," Construction and Building Materials, vol. 24, no. 3, pp. 315-321, 2010.

[8] H.-S. Shi, B.-W. Xu, and X.-C. Zhou, "Influence of mineral admixtures on compressive strength, gas permeability and carbonation of high performance concrete," Construction and Building Materials, vol. 23, no. 5, pp. 1980-1985, 2009.

[9] H. Binici, T. Shah, O. Aksogan, and H. Kaplan, "Durability of concrete made with granite and marble as recycle aggregates," Journal of Materials Processing Technology, vol. 208, no. 1-3, pp. 299-308, 2008.

[10] N. Banthia, A. Biparva, and S. Mindess, "Permeability of concrete under stress," Cement and Concrete Research, vol. 35, no. 9, pp. 1651-1655, 2005.

[11] M. I. Khan and C. J. Lynsdale, "Strength, permeability, and carbonation of high-performance concrete," Cement and Concrete Research, vol. 32, no. 1, pp. 123-131, 2002.

[12] M. Fauzi, M. Zain, Md. Safiuddin, T. K. Song, H. B. Mahmud, and Y. Matsufuji, "Influence of admixtures and quarry dust on the physcial properties of freshly mixed high performance 
concrete," Structural Engineering, Mechanics and Compuation, vol. 2, pp. 1381-1390, 2001.

[13] V. M. Malhotra and P. K. Mehta, Pozzolanic and Cementitious Materials, vol. 1 of Advances in Concrete Technology, Gordon and Breach, Amsterdam, The Netherlands, 1996.

[14] T. Celik and K. Marar, "Effects of crushed stone dust on some properties of concrete," Cement and Concrete Research, vol. 26, no. 7, pp. 1121-1130, 1996.

[15] A. Kermani, "Permeability of stressed concrete," Building Research and Information, vol. 19, no. 6, pp. 360-366, 1991.

[16] IS383-1970, Specification for Coarse and Fine Aggregate from Natural Soruces for Concrete, BIS Standard, New Delhi, India.

[17] IS10262-2009, Indian Standard Method for Concrete Mixture Proportioning, BIS Standard, New Delhi, India.

[18] ASTM C 1202-1979, Standard Test Method for Electrical Indication of Concrete's Ability to Resist Chloride Ion Penetration, American Society Testing of Materials, Philadelphia, Pa, USA.

[19] IS 3085-1965, Method of Test for Permeability of Cement Mortar and Concrete, BIS Standard, New Delhi, India. 

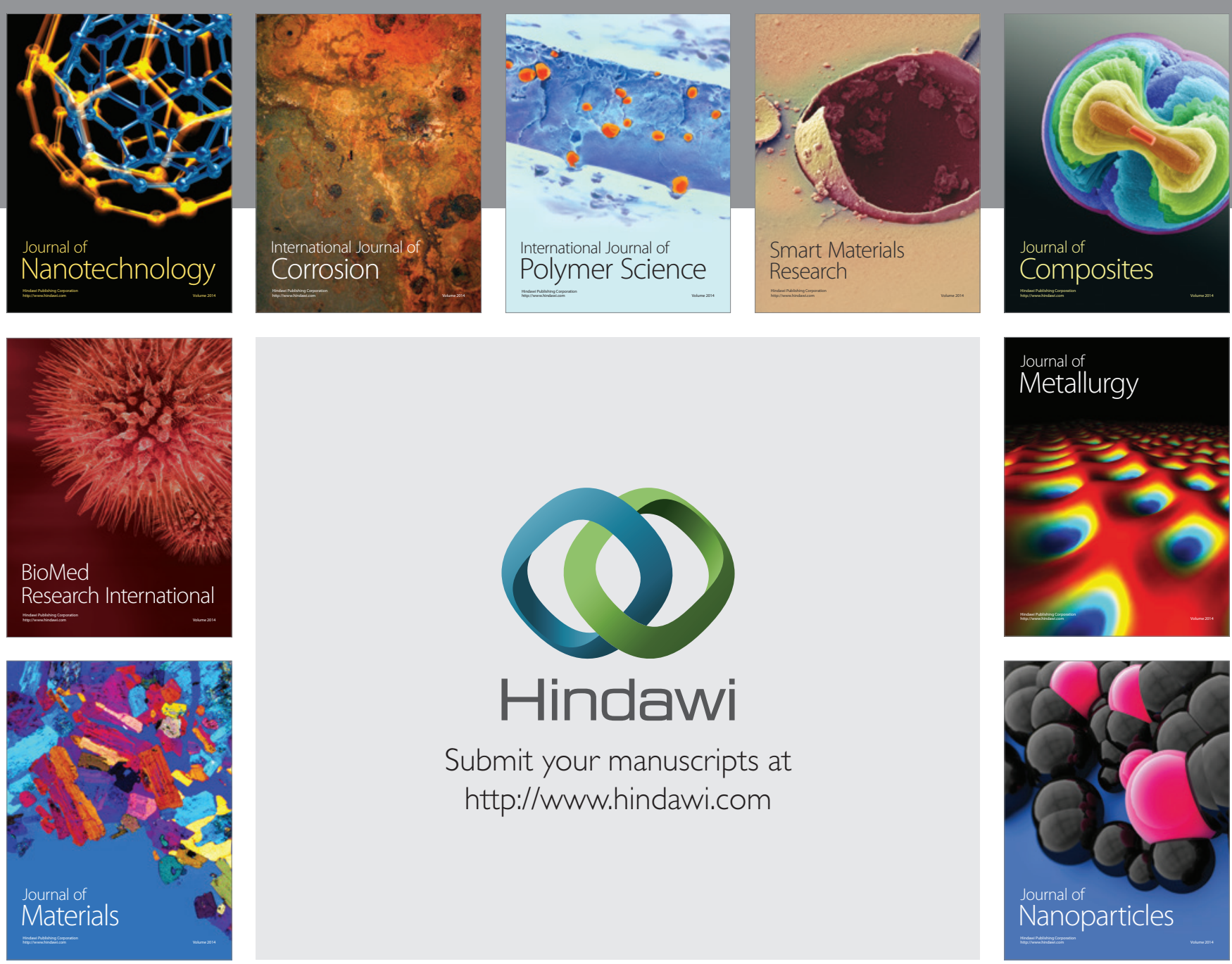

Submit your manuscripts at http://www.hindawi.com
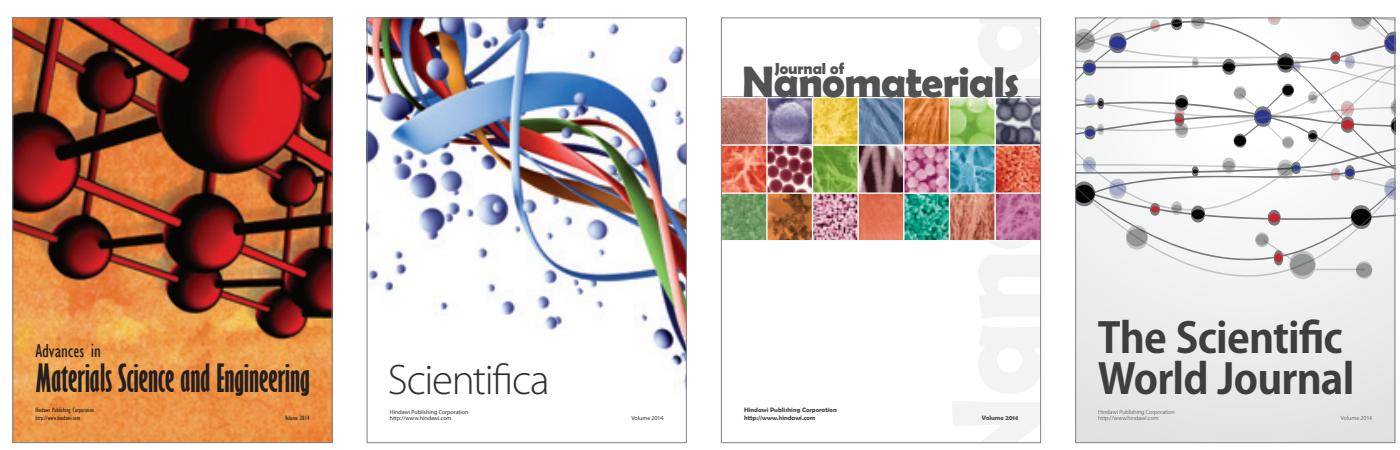

\section{The Scientific World Journal}
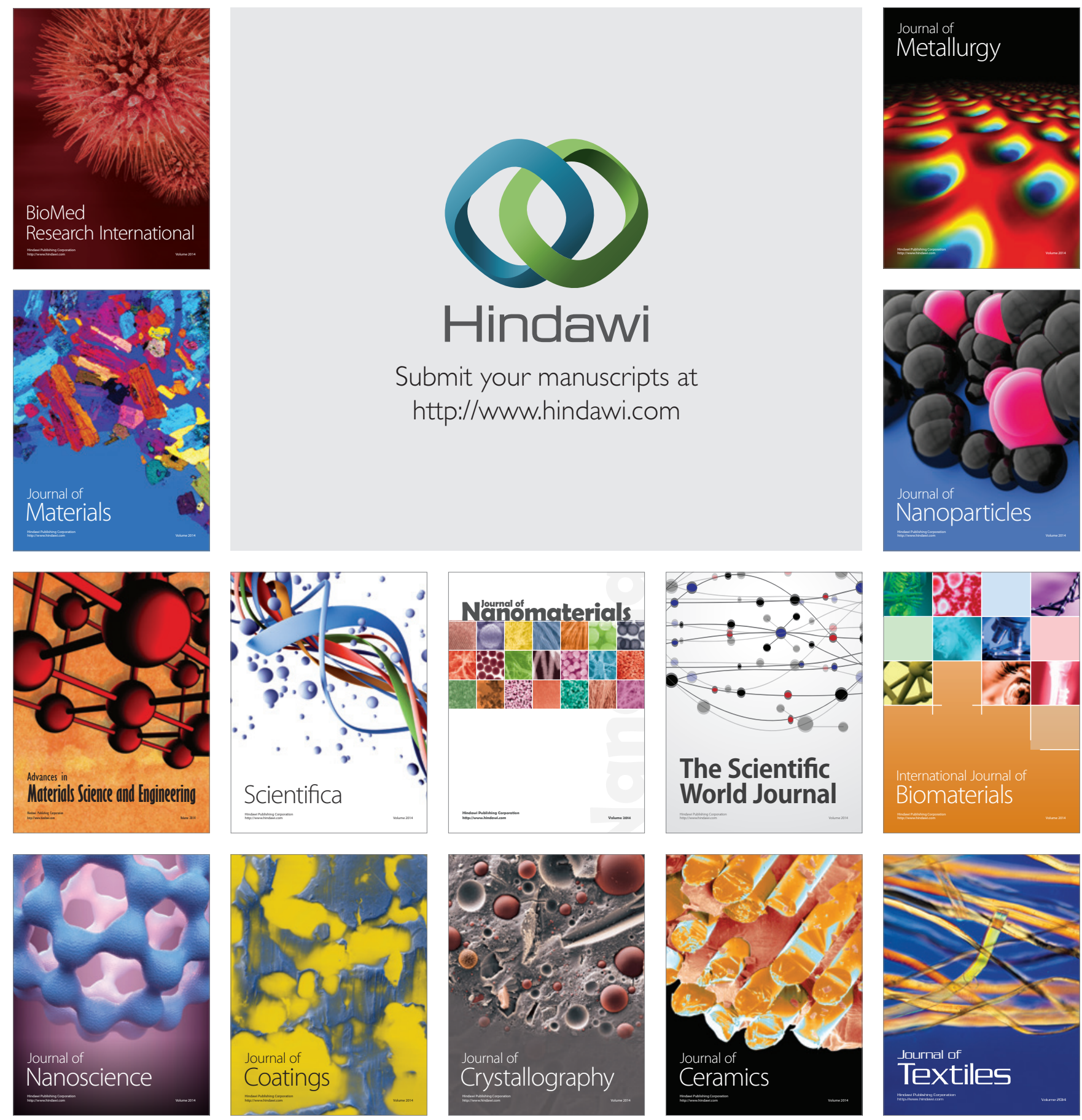